https://dx.doi.org/10.4314/iijikm.v10i1.7

Information Impact:

Journal of Information and Knowledge Management

Vol. 10 (1), June, 2019

ISSN: 2141-4297 (Print) ISSN: 2360-994X (Online)

\title{
Provision of Target-Specific Library Services for the Realization of Sustainable Development Goals (SDGs) in Developing Countries
}

\author{
Oyemike Victor Benson ${ }^{1}$, Chinwendu Chizoba Akpom², Ijeoma Dora Onyam ${ }^{3}$ \\ ${ }^{1}$ Department of Library \& Information Science, Federal Polytechnic, Nekede, Owerri, Imo State \\ ${ }^{2}$ Cataloguing Section, University Library, University of Nigeria Nsukka, Enugu Campus \\ ${ }^{3}$ University Library, University of Nigeria, Enugu Campus \\ Corresponding author bensonoyemike@gmail.com, greatoyemike@yahoo.com
}

\begin{abstract}
This paper examines the Role of Libraries in the Provision of Target-Specific Library Services for the Full Delivery of Sustainable Development Goals (SDGs) in developing countries. The narrative textual case study (NTCS) method was adopted for the study. The paper highlighted on the place of libraries in the actualization of SDGs Agenda. The target-specific library services to be provided by libraries and exact actions that libraries should take in line with the 2030 agenda for realization of sustainable development goals in developing countries were extensively tabulated for ease of understanding. The position of the paper is that libraries are key actors in the attainment of the SDGs and that the different types of libraries irrespective of nomenclature have a place in the 2030 agenda. The paper concludes that SDGs can be actualized if libraries are repositioned to provide target specific information services through partnership with other institutions and agencies.
\end{abstract}

\section{Keywords: Libraries, Sustainable Development Goals (SDGs), Target-Specific Library Services, Developing Countries}

\section{Introduction}

The Sustainable Development Goals (SDGs) programme was launched by the United Nations (UN) in September, 2015. The programme represents a global response to the inability to meet the targets set for the now rested Millennium Development Goals (MDGs). According to a statement credited to the UN, Agenda 2030 is a plan of action for people, planet and prosperity (United Nations, 2014). In the words of Nwachukwu (2018, p. 13), "it recognizes that eradicating poverty in all its forms and manifestations, is the greatest global challenge and an indispensable requirement for sustainable development". To ensure a more comprehensive approach, a total of 
seventeen (17) SDGs were identified - each of which has specific targets and timelines. The targets of these SDGs have direct impact on every member of the society both in developed and developing nations.

\section{The 2015 United Nations SDGs} agenda address the impediments to sustainable development such as poverty, hunger, ill-health, education, gender inequality and environmental sustainability (Anyaoku, 2017). The driving force behind SDG is nothing other than the idea of sustainable development that will be of benefit to the present and upcoming generations. SDGs are universal goals aimed at making the global world a better and safe environment. The SDGs are aspirations of humans towards the sustainable development of the global space for peaceful co-existence of the human species (Benson, Anyalebechi \& Amaechi, 2015; Amaechi, Benson, Dike \& Okere, 2016).

As noted by IFLA (n.d.), while the SDGs are universal goals, each country will be responsible for developing and implementing national strategies to achieve them, and will be expected to track and report progress. As these plans are developed, the library community in each country stands ready to show how libraries serve as partners to help meet the goals and local development needs.

Nevertheless, achieving the sustainable development goals requires the input of all institutions concerned and while some institutions' contributions can be direct, some can be indirect through support to other agencies (Anyaoku, 2017). Unarguably, the SDGs have targets that library and information science professionals can embrace in the course of their professional practices as strategies towards the full realization of the SDGs. Librarians according to Amaechi, Benson, Dike \& Okere (2016) should wake up and make their impact felt in this global move of making the universe better place.

The SDGs contain seventeen goals that are target specific towards various sectors of the economy, with each goal being focused on specific areas of the nation's economy as well as being development-oriented (Benson, Anyanwu, Onuoha \& Nwauwa, 2016). The target of each goal of the SDG is to address the contemporary challenges as they affect 
human life and existence on earth (Odu \& Edam-Agbor, 2017). The targets are global in nature and are universally applicable, taking into account different national realities, capacities and levels of development and respecting national policies and priorities (Benson, 2016).. According to Benson et al (2016), as the global initiative of SDGs has been unveiled by the United Nations (UN), is it left for individual countries to work out the modalities through which the SDGs could be transformed from vision to reality.

\section{Methodology}

This paper exclusively worked on secondary data. The narrative textual case study (NTCS) method was adopted for the study. Data were collected through the desk research approach from various sources,
The burning question here is how the various sectors (both public and private) can contribute to the full delivery of the SDGs agenda. It is the light of this that this paper aims at exploring the target-specific information services that the library could provide to ensure full delivery of the 2030 agenda. The specific objectives of this paper are to explain the place of the library in the actualization of the SDGs and also identify the target-specific library services that libraries can provide for full delivery of the SDGs in Nigeria

journals, research papers, internet resources and also through a number of discussions with professionals from the field of librarianship. Inferences were drawn from content analysis of various literatures relating to the subject under discourse.

\section{The Place of Libraries in the Actualization of SDGs Agenda}

Libraries have been acknowledged as social oriented and service organizations; Therefore, it is imperative that sustainable development goals should not be left in the hands of few because they are goals designed for all, to be embraced by all and for the benefit of all. In which case, libraries and information centres cannot be left out in this laudable venture (Benson, Amaechi, 
Anyalebechi \& Nse, 2017). Library services are indispensable to the educational, political, and social development of the rural population and the information gap between the urban and rural areas can be bridged by effective library services. Information services delivery should be given serious attention for any socio-economic development to take place, because it is a source of enlightenment for all and sundry ((Ebiwolate, 2010; Daudu \& Mohammed, 2013).

Baker and Musker (2017:59) argued that if agriculture and SDGs are to be achieved, smallholders, especially women, and low middle-income farmers must be able to access, analyze, and apply information to their production systems as improved access to information by farmers increases the likelihood of achieving the SDGs and its subgoals.

\section{According to Onah, Urom \&} Amanze-Unagha (2015), unhindered access to information in information agencies is required for the actualization of all the SDGs. They noted further that the actualization of the SDGs will be feasible provided all essential national infrastructure, including information agencies, are given the desired attention to contribute their quota in that direction. Similarly, Abdullahi and Abdullahi (2017) noted that government cannot achieve the SDGs alone and that the library, being a vital tool for national development needs to take up its responsibility in providing information services for the attainment of the SDGs.

According to Benson (2016), libraries and information centers over the years, have played significant roles in ensuring that certain policies of the government are actualized and sustained. Taking a cue from the academic community, libraries provide information services to ensure that academic programmes are accredited in our tertiary institutions as stipulated by National Universities Commission (NUC), National Board for Technical Education (NBTE) etc. This no doubt establishes that libraries and information centres have been at the front line of supporting government programmes and policies both at the local, regional, national and global levels. Recognizing the place of the libraries in the overall actualization of the SDGs, the International Federation of Library Associations and 
Benson, O.V, Akpom,C,C, Onyam, I,D: Provision of Target Specific Library Services for the Realization of Sustainable Development Goals (SDGs) in Developing Countries

Institutions (IFLA) has taken practical steps to demonstrate how libraries and information centres can contribute significantly to the attainment of the global initiatives. Therefore, stating that library and information centres have an important role to play in the realization of the Sustainable Development Goals (SDGs) is not an overstatement. The library no doubt is crucial to the realization of government polices at any level and by implication occupies a central place in the realization of SDGs (Ariola, Nwaigwe \& Anyalebechi, 2017). As social service oriented institution, it is pertinent that Library and Information Centres (LICs) align themselves with SDGs so that their impact can be felt (Benson, 2016).

Having explained the place of libraries in the actualization of the SDGs agenda, the next section of the paper will focus on target specific library services that can be provided towards full realization of the SDGs agenda 


\subsection{Target- Specific Library Services for full Delivery of Sustainable Development Goals in Nigeria}

Below is the various target specific goals that libraries can offer in line with the seventeen SDGs. Each of the columns contain the SDGs, the target-specific and actions to be taken respectively

\begin{tabular}{|c|c|c|c|}
\hline & GOALS & TARGET- SPECIFIC LIBRARY SERVICES & ACTIONS TO BE TAKEN \\
\hline 1 & End POVERTY in all its forms & $\begin{array}{l}\checkmark \text { Providing government with information on people/ areas living in } \\
\text { poverty that requires government attention; } \\
\checkmark \text { Identification of services that can be provided to help the people } \\
\text { living in poverty to come out of the situation; } \\
\checkmark \text { Identification of jobs that can be created by government in order } \\
\text { to raise income for people living in poverty; } \\
\checkmark \text { Identification of viable locations for establishment of small scale } \\
\text { business enterprises; } \\
\checkmark \text { Carrying out / supporting research focused on identification of } \\
\text { actual ratio of men, women and children living in poverty in } \\
\text { Nigeria; and } \\
\checkmark \text { Dissemination of relevant information that will bridge the gap } \\
\text { between men women equal rights to economic resources. }\end{array}$ & $\begin{array}{l}\checkmark \text { Library and information } \\
\text { professional should partner with } \\
\text { media houses and other } \\
\text { institution to ensure optimal } \\
\text { dissemination of information; } \\
\checkmark \text { Providing government } \\
\text { parastatals with verifiable and } \\
\text { reliable data on ratio of people } \\
\text { living in poverty }\end{array}$ \\
\hline
\end{tabular}

Information Impact: Journal of Information and Knowledge Management 10 (1), $2019 \quad$ Page 79 


\begin{tabular}{|c|c|c|c|}
\hline 2 & $\begin{array}{l}\text { End Hunger, Achieve Food } \\
\text { Security and Improved } \\
\text { Nutrition and Promote } \\
\text { Sustainable Agriculture }\end{array}$ & $\begin{array}{l}\text { - Provision and management of agricultural information to people in } \\
\text { rural areas; } \\
\text { - Providing agricultural extension workers with timely and reliable } \\
\text { research findings that can boost agricultural productivity; } \\
\text { - Creating platforms for sustainable collaboration with agricultural } \\
\text { extension agents to actualize agricultural development } \\
\text { programmes; and } \\
\text { - Analysis of the agricultural information needs of rural dwellers in } \\
\text { order to provide them with relevant and timely information; } \\
\text { - Assisting and providing farmers with information on local markets } \\
\text { for agriculture products; } \\
\text { - Provision and dissemination of information on nutrition } \\
\text { - Dissemination of information on the dangers and health risks of } \\
\text { over-consumption of imported foods; } \\
\text { - Dissemination of findings of research institutes on seedlings } \\
\text { improvement; and } \\
\text { - Timely dissemination of market information in relation to food } \\
\text { reserves; }\end{array}$ & $\begin{array}{l}\text { - Supporting Research Institutes } \\
\text { through the provision of relevant } \\
\text { information sources and conducive } \\
\text { environments for research }\end{array}$ \\
\hline
\end{tabular}

Information Impact: Journal of Information and Knowledge Management 10 (1), $2019 \quad$ Page 80 


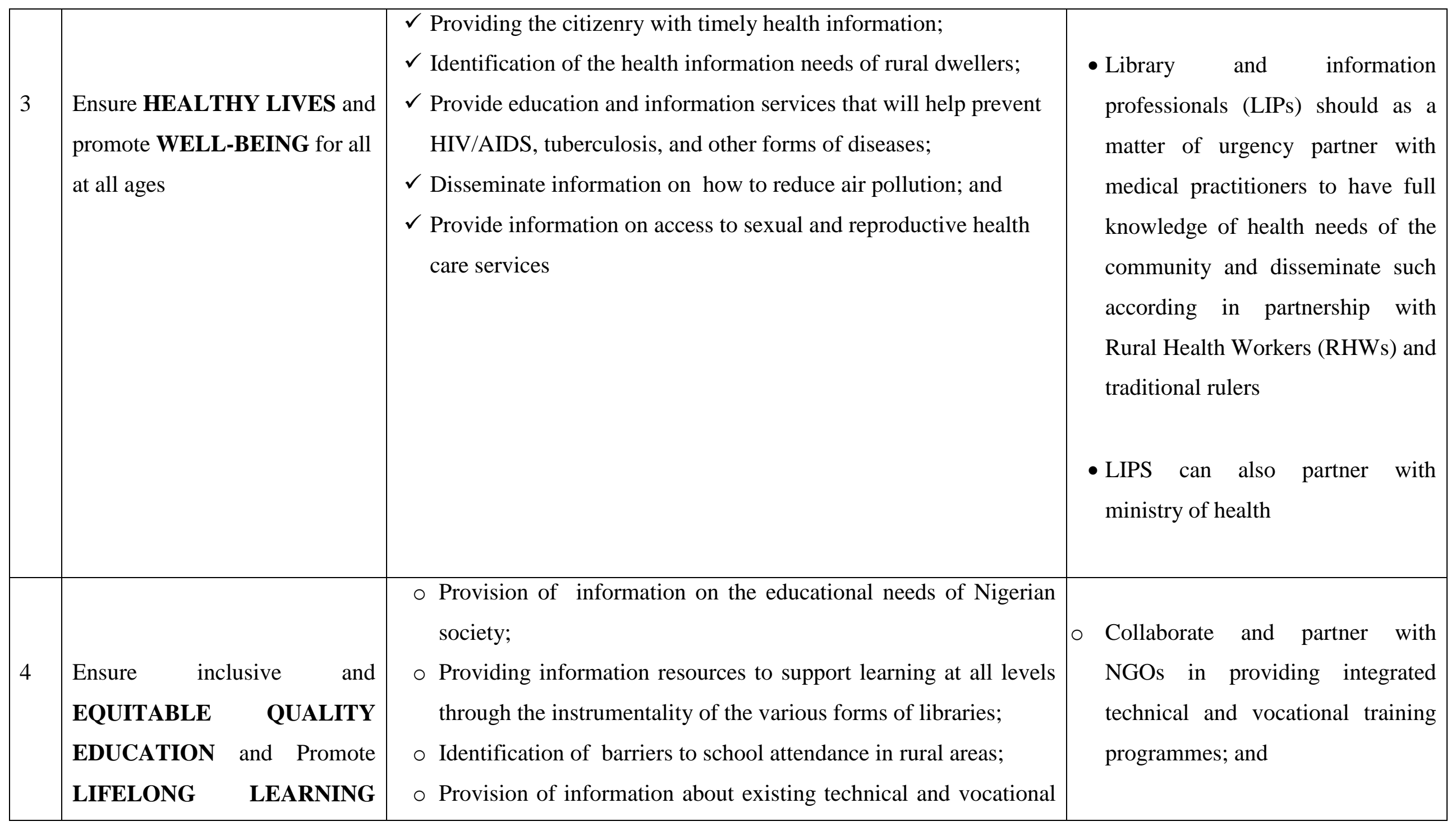




\begin{tabular}{|c|c|c|c|}
\hline & $\begin{array}{l}\text { OPPORTUNITIES for all } \\
\text { potential }\end{array}$ & $\begin{array}{l}\text { skills centres in Nigeria; } \\
\text { Providing sustainable platforms for all learners to have access to } \\
\text { sustainable education and acquire knowledge; and } \\
\text { Dissemination of information on scholarship opportunities } \\
\text { available to the school children }\end{array}$ & $\begin{array}{l}\text { o Partnering with other stakeholders } \\
\text { in the educational sector }\end{array}$ \\
\hline 5. & $\begin{array}{l}\text { Achieve GENDER } \\
\text { EQUALITY and empower all } \\
\text { women and girls }\end{array}$ & $\begin{array}{l}\checkmark \text { Dissemination of relevant information on gender equality; } \\
\checkmark \text { Creating awareness on the need for women empowerment; } \\
\checkmark \text { Provide information on violent and harmful practices against } \\
\text { women; } \\
\checkmark \text { Provide information on political platforms and opportunities that } \\
\text { women can easily participate; } \\
\checkmark \text { Assisting in carrying out researches on how best to eliminate all } \\
\text { forms of violence against all women; } \\
\checkmark \text { Provide and disseminate information on the dangers of forced } \\
\text { marriage/female genital mutilation; } \\
\checkmark \text { Help in sensitizing women's full and effective participation and } \\
\text { equal opportunities for leadership at all levels; } \\
\checkmark \text { Dissemination of information on sound policies and enforceable } \\
\text { legislation for the promotion of gender equality and the }\end{array}$ & $\begin{array}{l}\checkmark \text { Partnering with NGOS that } \\
\text { specialize on Gender Equity to } \\
\text { ensure full actualization of this } \\
\text { goal }\end{array}$ \\
\hline
\end{tabular}




\begin{tabular}{|c|c|c|c|}
\hline & & empowerment of all women and girls at all levels. & \\
\hline 6. & $\begin{array}{l}\text { Ensure AVAILABILITY and } \\
\text { SUSTAINABLE } \\
\text { MANAGEMENT of WATER } \\
\text { AND SANITATION for all }\end{array}$ & $\begin{array}{l}\text { - Provide information on the need for clean and water sanitation } \\
\text { - Carrying out research on specific areas that lack access to safe } \\
\text { affordable drinking water so that they can be integrated into } \\
\text { government project; } \\
\text { - Providing environmental information to urban and rural dwellers; } \\
\text { and } \\
\text { - Dissemination of information that will help in the reduction of } \\
\text { dumping of hazardous chemicals and materials within the } \\
\text { environment. }\end{array}$ & $\begin{array}{l}\text { - Partnering with NAFDAC to } \\
\text { disseminate information on fake } \\
\text { water industries to citizens; } \\
\text { - Partnering with Ministry of Health } \\
\text { to ensure that people have access } \\
\text { to vital information that promotes } \\
\text { clean environment. }\end{array}$ \\
\hline 7 & $\begin{array}{l}\text { Ensure access to } \\
\text { AFFORDABLE, RELIABLE, } \\
\text { SUSTAINABLE and } \\
\text { MODERN ENERGY for all }\end{array}$ & $\begin{array}{l}\text { Creating awareness on the need to ensure universal access to } \\
\text { affordable, reliable and modern energy services; and } \\
\text { Provide information on communities that lack access to } \\
\text { affordable energy }\end{array}$ & $\begin{array}{l}\text { - Supporting energy research } \\
\text { institutes } \\
\text { - Help in proposing a bill in support } \\
\text { of energy Research Institutes in } \\
\text { different states in Nigeria }\end{array}$ \\
\hline
\end{tabular}

Information Impact: Journal of Information and Knowledge Management 10 (1), $2019 \quad$ Page 83 


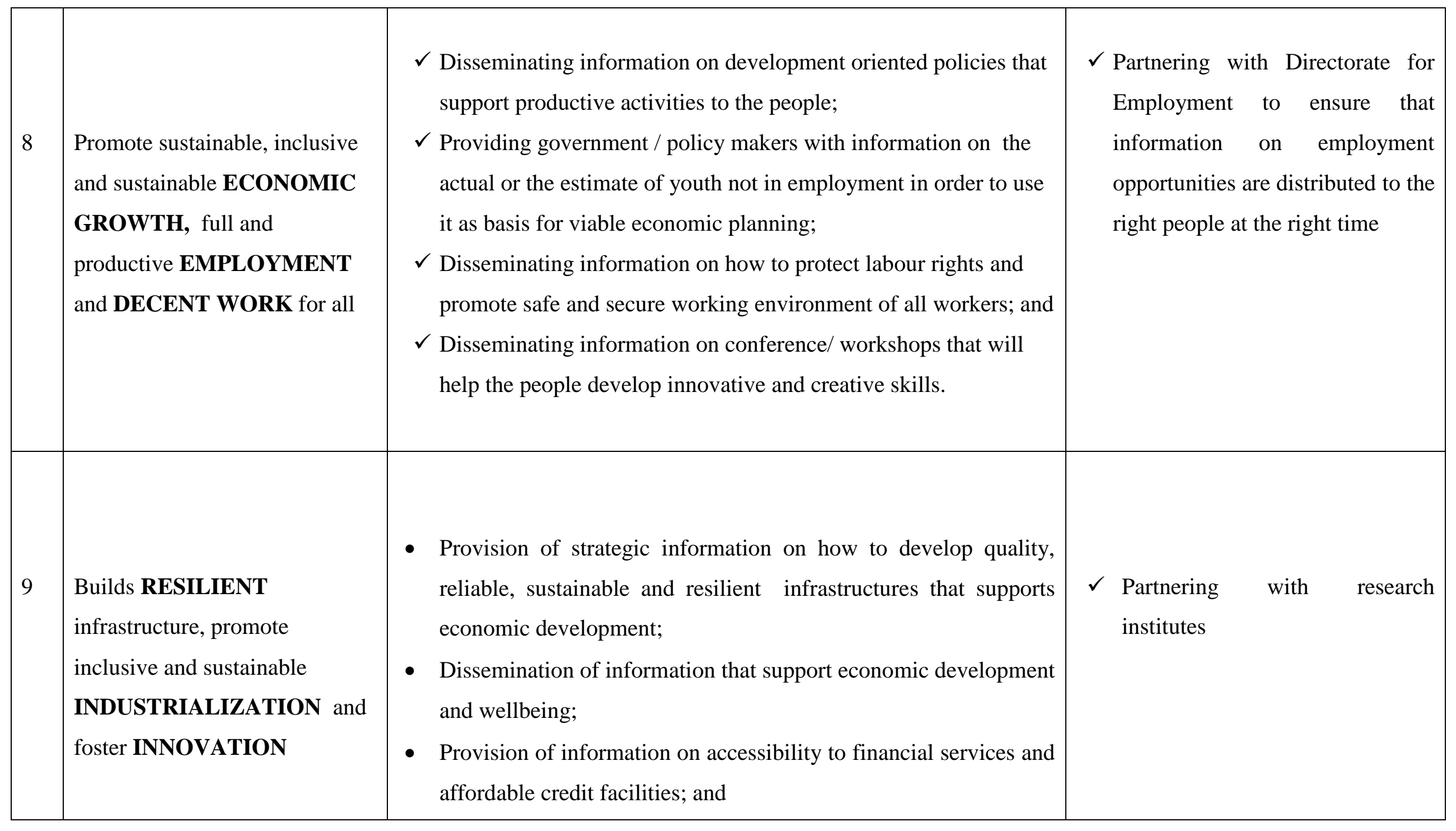

Information Impact: Journal of Information and Knowledge Management 10 (1), $2019 \quad$ Page 84 


\begin{tabular}{|c|c|c|c|}
\hline & & $\begin{array}{l}\text { - Ensuring equal access to ICT and the internet especially in the } \\
\text { rural areas }\end{array}$ & \\
\hline 10 & $\begin{array}{l}\text { Reduce INEQUALITY within } \\
\text { and among countries }\end{array}$ & $\begin{array}{l}\checkmark \text { Provide government with information and strategies on how to } \\
\text { achieve and sustain income growth of the bottom; } \\
\checkmark \text { identification of strategies on how to empower and promote the } \\
\text { social, economic and political equality inclusive of all } \\
\text { irrespective of age, sex, desirability, race, ethnicity, origin, } \\
\text { religion or economic or other status; } \\
\checkmark \text { promoting information that facilitates mobility of people, } \\
\text { including through implementation of planned and well managed } \\
\text { migration policies. }\end{array}$ & $\begin{array}{l}\checkmark \text { Partnering with media houses } \\
\text { and allied agencies to } \\
\text { disseminate information to all } \\
\checkmark \text { Partnering with International } \\
\text { organizations to carry out } \\
\text { viable research on how to } \\
\text { empower and promote the } \\
\text { social, economic and political } \\
\text { equality. }\end{array}$ \\
\hline 11 & $\begin{array}{l}\text { Make CITIES and HUMAN } \\
\text { SETTLEMENTS inclusive, } \\
\text { safe, resilient and sustainable }\end{array}$ & $\begin{array}{l}\checkmark \text { Providing people with information on affordable housing and } \\
\text { basic services; } \\
\checkmark \text { Providing information on affordable and sustainable transport } \\
\text { systems available to rural dwellers; } \\
\checkmark \text { Disseminating information on how to protect and safe guard } \\
\quad \text { cultural and natural heritage; } \\
\checkmark \text { Providing the people with information and awareness on proper }\end{array}$ & $\begin{array}{l}\checkmark \text { Partnering with media houses } \\
\text { and allied agencies to } \\
\text { disseminate information to all }\end{array}$ \\
\hline
\end{tabular}

Information Impact: Journal of Information and Knowledge Management 10 (1), $2019 \quad$ Page 85 


\begin{tabular}{|c|c|c|c|}
\hline & & $\begin{array}{l}\text { waste management; } \\
\checkmark \text { Sensitize the citizens on how to support economic, social and } \\
\text { environmental links between urban areas. }\end{array}$ & \\
\hline 12 & $\begin{array}{lr}\text { Ensure } & \text { sustainable } \\
\text { CONSUMPTION } & \text { and } \\
\text { PRODUCTION patterns } & \end{array}$ & $\begin{array}{l}\text { - Provision of information on how to achieve sustainable } \\
\text { management and efficient use of natural resources; } \\
\text { - Provision of information on how to reduce food waste/ food losses; } \\
\text { - Dissemination of information that promote public procurement } \\
\text { practices that are sustainable in accordance with national policies } \\
\text { and priorities; and } \\
\text { - Provision and dissemination of relevant information and awareness } \\
\text { for sustainable development; }\end{array}$ & $\begin{array}{l}\checkmark \text { Partnering with media houses } \\
\text { and allied agencies to } \\
\text { disseminate information to all }\end{array}$ \\
\hline 13. & $\begin{array}{l}\text { Take urgent action to combat } \\
\text { CLIMATE CHANGE and its } \\
\text { impacts }\end{array}$ & $\begin{array}{l}\checkmark \text { Provision of adequate information on climate related hazards and } \\
\text { natural disaster; } \\
\checkmark \text { Provision of information on human and institutional capacity on } \\
\quad \text { climate change }\end{array}$ & $\begin{array}{l}\text { Partnering with Ministry of Lands } \\
\text { and Environment for access to } \\
\text { information that should be } \\
\text { disseminated to people to ensure } \\
\text { that the oceans, seas and marine } \\
\text { resources are sustainably } \\
\text { conserved. }\end{array}$ \\
\hline
\end{tabular}

Information Impact: Journal of Information and Knowledge Management 10 (1), $2019 \quad$ Page 86 


\begin{tabular}{|c|c|c|c|}
\hline 14 & $\begin{array}{l}\text { Conserve and sustainably use } \\
\text { the OCEANS, SEAS and } \\
\text { MARINE RESOURCES for } \\
\text { sustainable development }\end{array}$ & $\begin{array}{l}\text { o Dissemination of information on how to prevent and significantly } \\
\text { reduce marine pollution of all kinds; } \\
\text { o Provision and dissemination of information on how to manage and } \\
\text { protect marine and coastal ecosystems to avoid adverse impacts; } \\
\text { o Promotion and dissemination of international and national laws } \\
\text { related to conservation of coastal marine areas. }\end{array}$ & $\begin{array}{l}\text { O Partnering with Ministry of Lands } \\
\text { and Environment for access to } \\
\text { information that should be } \\
\text { disseminated to people to ensure } \\
\text { that the oceans, seas and marine } \\
\text { resources are sustainably } \\
\text { conserved. }\end{array}$ \\
\hline 15 & $\begin{array}{l}\text { Protect, restore and promote } \\
\text { sustainable use } \\
\text { TERRESTRIAL } \\
\text { ECOSYSTEMS, sustainably } \\
\text { manage FORESTS, combat } \\
\text { DESERTIFICATION and halt } \\
\text { and reverse } \\
\text { DEGRADATION and halt } \\
\text { BIODIVERSITY loss }\end{array}$ & $\begin{array}{l}\checkmark \text { Disseminating and promoting information on the implementation } \\
\text { of sustainable management of all types of forests; } \\
\checkmark \text { Provide information on how to take urgent and significant actions } \\
\text { to reduce degradation of natural habitat and halt the loss of } \\
\text { biodiversity. }\end{array}$ & $\begin{array}{l}\checkmark \text { Partnering with Ministry of } \\
\text { Lands and Environment for access } \\
\text { to information that should be } \\
\text { disseminated to people to ensure } \\
\text { that the oceans, seas and marine } \\
\text { resources are sustainably } \\
\text { conserved. }\end{array}$ \\
\hline & Promote PEACEFUL and & o Creating awareness on how to reduce all forms of violence and & \\
\hline
\end{tabular}




\begin{tabular}{|c|c|c|c|}
\hline 16 & $\begin{array}{l}\text { inclusive societies for } \\
\text { SUSTAINABLE } \\
\text { DEVELOPMENT, provide } \\
\text { access to JUSTICE for all and } \\
\text { build effective, accountable and } \\
\text { inclusive institutions at all } \\
\text { levels. }\end{array}$ & $\begin{array}{l}\text { related death rates; } \\
\text { o Providing information on how to substantially reduce corruption } \\
\text { and bribery in all its forms; } \\
\text { o Provision and dissemination of information that ensure responsive, } \\
\text { inclusive, participatory and representative decision-making; and } \\
\text { o Provision of information that will ensure public access to } \\
\text { information that will help in protecting fundamental freedoms in } \\
\text { accordance with national and international legislations }\end{array}$ & $\begin{array}{l}\text { Partnering with } \\
\text { Governmental Organization } \\
\text { (NGOs) promote peaceful and } \\
\text { inclusive societies for sustainable } \\
\text { development, provide access to } \\
\text { justice for all }\end{array}$ \\
\hline 17. & $\begin{array}{l}\text { Strengthen the means of } \\
\text { implementation and revitalize } \\
\text { the GLOBAL } \\
\text { PARTNERSHIP for } \\
\text { sustainable development. }\end{array}$ & $\begin{array}{l}\text { - Provision of information on how best to improve domestic capacity } \\
\text { for tax and other revenue collection; } \\
\text { - Dissemination of information that encourage and promote effective } \\
\text { public-private and civil society partnership; and } \\
\text { - Dissemination of high-quality, timely and reliable data relevant to } \\
\text { national planning. }\end{array}$ & \\
\hline
\end{tabular}

\section{Source: Adapted from Sustainable Development Goals and Targets}




\section{Conclusion}

This paper has demonstrated that libraries are key actors in the attainment of the SDGs. The different types of libraries irrespective of nomenclature have a place in the 2030 agenda. As shown in this discourse, SDGs can be actualized if libraries are repositioned to provide target specific information services. More importantly, this can be realized by libraries partnering with other institutions and agencies to provide these target-specific goals. As rightly noted by Benson, Amaechi,

\section{References}

Abdullahi L. U. \& Abdullahi, F. (2017). Academic libraries: imperative tools for achieving sustainable development goals in Nigeria. Journal of Information Resource Management (JIRM), 5 (1), 45 - 54.

Amaechi, N. M., Benson, O. V., Dike, C. A. \& Okere, I. V. (2016). Eradication of poverty and hunger within the sustainable development goals framework: the role of library and
Anyalebechi and Nse, (2017), libraries remain a social service organization, and as such, it is imperative that sustainable development goals should not be left in the hands of few because it is goals designed for all, to be embraced by all and for the benefit of all. The paper therefore, concludes that libraries occupy central position in the overall actualization of the sustainable development goals (SDGs) and must be ready to contribute its quota to the full realization of these goals through the provision of library and information services that are SDGs target-specific.

information science professionals (LISP). Paper presented during the $54^{\text {th }}$ National Conference / Annual General Meeting of Nigerian Library Association held at FUNTAJ International School Auditorium, Gudu, Abuja, 24 - 29 July, 2016.

Anyaoku, E. N. (2017). Medical libraries and achieving sustainable development goals in Nigeria. Nigerian Libraries, $50(1), 53-61$. 
Ariola, I. A., Nwaigwe, U. \& Anyalebechi, L. I. (2017). Expectations of Central Bank of Nigeria $(\mathrm{CBN})$ library towards the realization of sustainable development goals (SDGs) in Nigeria. Journal of Applied Information Science and Technology, 10, (1), 133 139

Benson, O. V., Amaechi, N. M., Anyalebechi, L. I. \& Nse, J. (2017). Sustainable development goals (SDGs): taking the public and community library services beyond the library walls. Paper Presented at the $4^{\text {th }}$ African Library Summit \& $2^{\text {nd }}$ AfLIA Conference, $16^{\text {th }}-19^{\text {th }}$ May 2017, Djeuga Palace Hotel, Yaounde, Cameroon

Benson, O. V. (2016). Library and Information Services (LIS): Our Expectations and Commitment to Sustainable Development Goals (SDGs) in Nigeria. Paper Presented during the $54^{\text {th }}$ National Conference/ Annual General Meeting of Nigerian Library Association, held at FNUTAJ International School Auditorium, Gudu, Abuja, 24-29 July2016.
Benson, O. V., Anyalabechi, L. I. \& Amaechi N. M. (2015). Sustainable development goals (SDGs) in developing countries: the expectations of community and public libraries. Nigerian Library Link, 14 (1\&2), 63 77.

Benson, O. V., Anyanwu, E. U., Onuoha C. O. \& Nwauwa, E. B. (2016). Priorities and challenges of actualizing sustainable development goals: perspective of library and information professional in Owerri, Nigeria. Journal of Applied Information Science and Technology, 9 (2),40 - 46.

Nwachukwu, I. (2018). Sustainable community development, Umudike: Society for Community and Communication Development Research, Michael Okpara University of Agriculture.

Odu, J. O. \& Edam-Agbor, I. B. (2017). Library and information science processional training and the achievement of sustainable development goals in Nigeria. Paper Presented at the NLA 2017 Conference, $23^{\text {rd }}-27^{\text {th }}$ July, 2017 
Benson, O.V, Akpom,C,C, Onyam, I,D: Provision of Target Specific Library Services for the Realization of Sustainable Development Goals (SDGs) in Developing Countries

Onah, E. A., Urom, O. C. \& AmanzeUnagha, B. (2015). Emergence of sustainable development goals and the case for rebranding information agencies for actions in Nigeria. Ebonyi Journal of Library and Information Science, 2 (1), 217 - 225

United Nations (2014). UN General Assembly's Open Working Group Proposal on sustainable development goals. Retrieved from: http://www.sustainable development.un.org/content/document s/453

International Federation of Library Associations and Institutions (IFLA) (n.d.). Access and opportunity for all: How libraries contribute to the United Nations 2030 Agenda. Available online at:

http://www.ifla.org/files/assets/hq/topics /librariesdevelopment/documents/access-andopportunity-for-all.pdf 